\title{
Bocaiuva jelly: preparation, physicochemical and sensory evaluation
}

\author{
Vanessa Mandu da Silva ${ }^{1}$, Raquel Pires Campos$^{2}$, Aurélio Vinícius Borsato ${ }^{3}$, \\ Camila Jordão Candido ${ }^{4}$, Juliana Rodrigues Donadon 5

\begin{abstract}
Bocaiuva cultivation, mainly in Mato Grosso do Sul, has a strong socio-economic and environmental appeal. Bocaiuva pulp is rich in nutrients and has antioxidant action, and its use in the formulation of jellies minimizes post-harvest losses and provides market with a product with high nutritional value throughout the year. The aim of this work was to elaborate and chemically and sensorially evaluate jellies produced with bocaiuva pulp (Acrocomia aculeata (Jacq.) Lodd ex Mart) of two morphotypes, orange and yellowish pulp, characterizing fresh pulps and jellies regarding physical and chemical parameters. Diluted pulp and sugar (1: 1), pectin and citric acid were used in jelly processing. Fresh pulp and jelly made with yellowish pulp showed higher contents of total phenols and antioxidant capacity. Jellies did not differ in nutritional constituents, except for fixed mineral residue, in which the yellowish pulp had higher value. Jelly with orange pulp had acceptability index over $80 \%$ in the analyzed attributes (global aspect, flavor and consistency) and in the purchase intention, statistically superior to jelly made with yellowish pulp. Different native fruit morphotypes can give rise to differentiated and valued processed products.
\end{abstract} \\ Index terms: Acrocomia aculeata (Jacq.) Lodd ex. Mart, processing, acceptability, bioactive.

\section{Geleia de bocaiuva: elaboração, avaliação físico-química e sensorial}

Corresponding author: juliana.donadon@ufms.br

Received: November 17, 2017. Accepted: April 05, 2018.

Copyright: All the contents of this journal, except where otherwise noted, is licensed under a Creative Commons Attribution License.

\section{(cc) $\mathbf{E Y}$}

Resumo - O aproveitamento da bocaiuva, no Mato Grosso do Sul, tem forte apelo socioeconômico e ambiental. A polpa da bocaiuva é rica em nutrientes e possui ação antioxidante, sendo que sua utilização na formulação de geleias minimiza as perdas pós-colheita e fornece ao mercado um produto com alto valor nutricional o ano todo. Objetivou-se elaborar e avaliar, química e sensorialmente, as geleias produzidas com polpas de bocaiuva (Acrocomia aculeata (Jacq.) Lodd ex. Mart) de dois morfotipos, coloração alaranjada e amarelada, caracterizando as polpas in natura e as geleias quanto aos parâmetros físicos e químicos. Utilizou-se, no processamento da geleia, polpa diluída e açúcar (1:1), pectina e ácido cítrico. A polpa in natura e a geleia elaborada com polpa amarelada apresentaram maiores teores de fenóis totais e capacidade antioxidante. As geleias não diferiram entre si quanto aos constituintes nutricionais, com exceção do resíduo mineral fixo, em que a de polpa amarelada apresentou maior valor. A geleia com polpa alaranjada apresentou índice de aceitabilidade superior a $80 \%$ nos atributos analisados (aspecto global, sabor e consistência) e na intenção de compra, superior estatisticamente à geleia com polpa amarelada. Diferentes morfotipos de frutos nativos podem originar produtos processados, diferenciados e valorizados. Termos para indexação: Acrocomia aculeata (Jacq.) Lodd ex. Mart, processamento, aceitabilidade, bioativos. 


\section{Introduction}

Acrocomia aculeata (Jacq.) Lodd ex. Mart. is a fruit tree native to the Cerrado and tropical forests (LORENZI, 1996) popularly known as bocaiuva or macaúba. Bocaiuva belongs to the family Arecaceae and is distributed in higher concentrations in the states of Minas Gerais, Goiás, Mato Grosso and Mato Grosso do Sul (SANTOS JÚNIOR et al., 2012).

Bocaiuva cultivated in Mato Grosso do Sul and has strong socio-economic and environmental appeal, since it is an abundant natural resource of extreme importance for biodiversity and potential use for different purposes, mainly food. Extractivism is still the predominant production system, which is extremely important for the generation of labor and income for rural communities.

The phenotypic variability of bocaiuva was evaluated in three native populations of the Pantanal region, in the city of Corumbá, MS, Brazil, where there were variations in fruit size and shape, being identified mainly by two colors of higher occurrence such as orange (17.1\%) and yellow epicarp (31.7\%); and orange (30.0\%) and yellow mesocarp (34.29\%) (VIANNA et al., 2013). According to Vianna (2011), the different bocaiuva morphotypes differentiate by taste and lipid content.

Bocaiuva pulp is rich in $\beta$-carotene, the main identified carotenoid, is source of copper, iron and zinc, which may contribute to the enrichment of the regional $\operatorname{diet}$ (RAMOS et al., 2008). $\beta$-carotene has provitamin A activity (NELLIS et al., 2017), an antioxidant action that can directly or indirectly be correlated with health benefits (ZIMMERMANN; KIRSTEN, 2008). Antioxidants are substances that have the ability to retard or inhibit the oxidation of oxidizable substrates by enzymatic or non-enzymatic action (MORAIS et al., 2009), as well as potential to induce specific cell responses according to the compound (ZIMMERMANN, KIRSTEN, 2008).

Bocaiuva fruiting occurs throughout the year, presenting mature fruits between the months of September and December. It is consumed in the fresh form or in processed products such as ice creams and flours (SALIS; MATTOS, 2009).

Jelly is a product that is obtained from the cooking of fruit, pulp or juice, added of sugar and water until gelatinous consistency is obtained. It is classified as regular when it has $40 \%$ pulp and $60 \%$ sugar or extra when made with $50 \%$ pulp and $50 \%$ sugar. The addition of pectin and acidulants is necessary to overcome deficiencies in the natural content of pectin or fruit acidity. Its consistency should have semisolid appearance (BRASIL, 1978).

Bocaiuva can be used in the formulation of jellies, whose final product can vary in taste and color according to the physicochemical characteristics of raw materials, guaranteeing fruit utilization during harvest and minimizing post-harvest losses, providing market a product with high nutritional value throughout the year.

The objective of this study was to elaborate, characterize and evaluate the acceptance of bocaiuva jellies made with yellow and orange pulp fruits aiming the use of fruit and the development of product with added value, enabling the generation of income for rural communities of the State of Mato Grosso do Sul, as well as characterize pulps used in processing.

\section{Material and methods}

Mature bocaiuva fruits were collected in 10 individuals of two morphotypes differentiated by pulp coloring in the month of August, 2015, along the BR 262 highway, $40 \mathrm{~km}$ from the municipality of Corumbá, MS. Fruits were separated in batches according to morphotype, washed in running water and sanitized with $200 \mathrm{mg} \mathrm{L}^{-1}$ chlorinated solution, placed on previously sanitized stainless steel benches for drying the surface water with natural air. For the evaluation of the physical characteristics of fruits of each batch, 25 fruits were used, determining the mass of the whole fruit, the bark (epicarp) and pulp (mesocarp) yield by weighing 25 fruits, bark and pulp, in a AND HR-202 analytical scale to obtain the mean values, the equatorial and longitudinal diameter, with the aid of a digital caliper (ZASS 6) and the bark and pulp coloring using Minolta CR- $400 \mathrm{~b}$ reflectometer, which expresses color in L*, a* and b* (MINOLTA CORP, 1994), taking two readings per fruit.

To determine the peeling and pulping time of fruits of each batch, 3 people and 20 fruits each were used, totaling 60 units of each type, and results were expressed in $\mathrm{kg} \mathrm{h}^{-1}$. The peeling and pulping of fruits were performed manually with the aid of a stainless knife and time was determined by means of a digital timer. Pulps were stored at $-18^{\circ} \mathrm{C}$ until the chemical characterization and preparation of jellies.

Two jelly formulations were prepared, the first one using orange pulp fruits and the second, yellowish pulp fruits, according to the extra 1: 1 classification (diluted fruit pulp: sugar), using $1 \%$ pectin for gelation in relation to total mass and citric acid. The percentage of acid required to adjust the $\mathrm{pH}$ of pulps to 3.3 was determined by means of the acidification curve in $100 \mathrm{~g}$ of diluted pulp (BERBARI; PASCHOALINO, 1997). Pulps were diluted in water as they had solid appearance. The percentage of water and pulp of formulations was determined in preliminary tests choosing, regardless of formulation, the proportion that resulted in viscous dilution with bocaiuva pieces.

In the formulation with orange pulp, $20 \%$ of pulp and $80 \%$ of water were used, while in yellowish pulp, $25 \%$ of pulp and $75 \%$ of water. From the total pulp mass, $50 \%$ were submitted to cooking with the water 
added in the dilution, for 10 minutes. After cooking, the product was homogenized in a Philips $550 \mathrm{~W}$ blender. Then, the remainder of the pulp chopped into pieces of approximately $0.5 \mathrm{~cm} \times 0.5 \mathrm{~cm}$ was added. The lowest pulp percentage in the orange pulp formulation was due to the consistency of the diluted pulp, after homogenization, with emulsion appearance. The end point of the jelly was determined using methodology of Bianchini and Coutinho (2007). Pulps and jellies were evaluated for centesimal composition: moisture, fixed mineral residue, proteins (using conversion factor of 6.25), lipids, carbohydrates and fibers (calculated by difference). In order to determine the energy value, the Atwater conversion factor was used (INSTITUTO ADOLFO LUTZ, 2005).

Soluble solids (SS), pH, ascorbic acid, total phenols and antioxidant capacity were determined in fresh pulps and jellies. Soluble solids (SS) contents, expressed as ${ }^{\circ}$ Brix, were determined using digital refractometer. For $\mathrm{pH}$, potentiometer calibrated with $\mathrm{pH} 7.0$ and 4.0 buffer was used, according to AOAC methodology (1997). Titratable acidity (TA) was determined in pulps by titration with standard solution of $0.1 \mathrm{~N}$ sodium hydroxide (INSTITUTO ADOLFO LUTZ, 2005). Ratio was determined by the relationship between soluble solids and titratable acidity (SS / TA).

Total phenols and antioxidant capacity were evaluated in hydrocetonic extracts ( $70 \%$ acetone) in fresh pulp and jelly (ROESLER et al., 2007). Extracts were submitted to colorimetric reaction for determination of phenolic compounds according to Swain and Hills (1959). In determining the antioxidant capacity, the $\mathrm{CI}_{50}$ value was defined as the final concentration of the integral extract required to decrease the initial DDPH concentration by $50 \%$.

Analyses were evaluated in pulps and jellies in three replicates and each replicate in duplicate, with $300 \mathrm{~g}$ of pulp / jelly. The averages of results were compared by the tukey test at $5 \%$ probability.

The sensory analysis of jellies was carried out after approval of the Ethics Research Committee of the Federal University of Mato Grosso do Sul under number 46179915.9.0000.0021. For the jelly acceptance tests, a 9-point structured hedonic scale was used, where $1=$ disliked very much; 2 = disliked moderately; $3=$ disliked slightly; $4=$ Neither liked or disliked; $5=$ liked slightly; 6 $=$ liked moderately and $7=$ liked very much. The evaluated attributes were: global aspect, flavor and consistency. The purchase intention was evaluated through a structured five-point scale, where 1 = certainly would not buy; 2 = possibly would not buy; 3 = maybe would buy / maybe would not buy; 4 = possibly buy and $5=$ certainly buy (INSTITUTO ADOLFO LUTZ, 2005).

Jellies were evaluated by 70 judges of both sexes in the age group of 18-60 years, except for quilombolas and indigenous people, and those with glycemic diseases or allergies to any ingredient of the product, after signing of the TCLE (Free and Informed Consent Form). Jelly samples were identified with random numbers and coded with three digits, being served with crackers and mineral water to clean the palate. The acceptance index (AI) of evaluated parameters was determined according to the formula: $\mathrm{AI}(\%)=\mathrm{Ax} 100 / \mathrm{B}(\mathrm{A}=$ average score obtained for the product, $\mathrm{B}=$ maximum score given to the product) (DUTCOSKY, 2013).

\section{Results and discussions}

Orange pulp bocaiuva fruits presented higher unit mass, pulp yield, equatorial and longitudinal diameters, differing from yellowish pulp fruits (Table 1). The results obtained for orange pulp fruits were similar to values found in bocaiuva fruits collected in Dourados, MS, which had diameters of $34.68 \mathrm{~mm}$ and $33.39 \mathrm{~mm}$, respectively, and for those of yellowish pulp, values close to those obtained in fruits collected in Presidente Epitácio, SP, with values of $33.14 \mathrm{~mm}$ and $31.65 \mathrm{~mm}$, respectively (SANJINEZ-ARGANDOÑA; CHUBA, 2011).

The peeling time and manual pulping differed statistically between fruits of different morphotypes. In yellowish pulp fruits, the greater adherence of the pulp to the bark resulted in longer peeling time (Table 1). The variation in the adhesion of the epicarp to the mesocarp according to the different pulp color was identified by Vianna et al. (2013).

For the pulping time, i.e., the separation of the pulp from the endocarp, the average time presented for orange pulp fruits was $1.36 \mathrm{~kg} \mathrm{~h}^{-1}$ and for those with yellowish pulp of $0.70 \mathrm{~kg} \mathrm{~h}^{-1}$. The highest pulp yield was obtained for orange pulp fruits, $53.36 \%$ (Table 1), facilitating and reducing the pulping time. The yields found in this study were higher than those described by Ramos et al. (2008), who through manual work obtained $21.44 \%$ of bark and $44.22 \%$ of pulp, in bocaiuva fruits with $21.83 \mathrm{~g}$. The easier peeling and pulping of orange pulp fruits and the higher yield of this pulp are related to the preference of use of this morphotype by rural communities.

Color is represented by three different parameters, $\mathrm{L}^{*}, \mathrm{a}^{*}$ and $\mathrm{b}^{*}$, where $\mathrm{L}^{*}$ represents luminosity, which varies from 0 to 100 , with value 100 indicating white, and value 0 , no luminosity or black. The $a^{*}$ value represents colors ranging from red $\left(+a^{*}\right)$ to green $\left(-a^{*}\right)$ and $b^{*}$ represents colors ranging from yellow $\left(+b^{*}\right)$ to blue $\left(-b^{*}\right)$. Table 2 shows that orange pulp barks did not differ from those of orange pulp in terms of luminosity, with values of 42.18 and 40.86 , respectively. Orange pulp fruits presented higher $a^{*}$ and $b^{*}$ values $\left(a^{*}=10.95 ; b *=\right.$ 40.22), indicating more shades of red and yellow (Table 2 ).

Bocaiuva fruits popularly known to present orange pulp showed higher $\mathrm{a} *$ and $\mathrm{b} *$ values $\left(\mathrm{a}^{*}=19.25 ; \mathrm{b}^{*}=\right.$ $71.81)$, compared to those of yellowish pulp $\left(a^{*}=13.17\right.$; 
$\left.b^{*}=63.59\right)$, indicating more shades of red and yellow. Regarding luminosity, orange pulp fruits showed darker coloration because they presented lower luminosity values $(\mathrm{L}=57.47)$ (Table 2).

When evaluating fresh pulps of the different morphotypes, it was verified that there were no differences between them regarding soluble solids, $\mathrm{pH}$ and ascorbic acid, but orange pulp fruits presented higher Ratio, of 24.39 (Table 3). Soluble solids contents found in pulps were similar to those reported by Sanjinez-Argandoña and Chuba (2011). Jellies elaborated with orange pulp presented $67.5^{\circ}$ Brix and the yellow pulp $61.5^{\circ}$ Brix (Table 3).

Fresh pulps did not differ in $\mathrm{pH}$ (mean of 5.89); however, orange pulp jelly had higher $\mathrm{pH}$ value (3.93) and yellowish pulp jelly showed $\mathrm{pH}$ of 3.25 (Table 3 ), probably due to the chemical variations between fruits, considering that the percentage of citric acid added was determined in $100 \mathrm{~g}$ of diluted pulp.

The $\mathrm{pH}$ of jelly for optimal consistency is 3.3 , but when below 3.0, it may favor the occurrence of syneresis, liquid exudation, causing unpleasant appearance, and above 3.3, firmness is reduced (JACKIX, 1988), which did not occur in this work, in orange pulp jelly, showing higher $\mathrm{pH}, 3.93$ (Table 3) and firm but soft consistency, probably due to the high pectin content in the sample, or other component capable of forming gum.

According to Brandão and Andrade (1999), pectins with high degree of methoxylation gelify in acid medium in the presence of high sugar concentrations. According to these authors, the pectin / sucrose system is quite complex, during the gelation process as a function of temperature, with predominance of hydrogen interactions at low temperatures and hydrophobic interactions at higher temperatures, which affects the structure of the network and the viscoelastic behavior at the sol-gel phase transition point.

Ascorbic acid content in fresh pulps was higher than that obtained by Sanjinez-Argandoña and Chuba

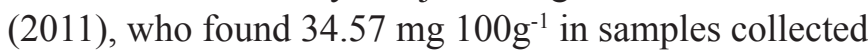
in Presidente Epitácio-SP. Bocaiuva jellies did not differ in relation to ascorbic acid content (Table 3) and the values obtained were lower than those found by Gomes et al. (2013), in passion fruit jelly with carrot $(31.37 \mathrm{mg}$ $\left.100 \mathrm{~g}^{-1}\right)$. The processing of fresh pulp into jelly led to a decrease in ascorbic acid content, but jellies showed 10.69-

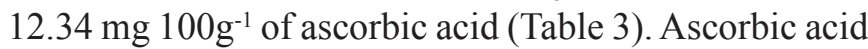
content in pulp and jellies is significant, considering that in citrus fruits, values vary between 21.47 and $84.03 \mathrm{mg}$ ascorbic acid $100 \mathrm{~mL}^{-1}$ of juice, in mandarin and orange, respectively (COUTO, CANNIATTI-BRAZACA, 2010). Scientific researches point to the role of ascorbic acid in the prevention and / or treatment of cancer (MATA et al., 2016).

According to Sucupira et al. (2012), the heat treatment applied in processing leads to the destruction of pathogens and inactivation of undesirable enzymes, but also to the loss of vitamins that vary according to the cooking method and type of food. This degradation depends on factors such as temperature, presence of oxygen, light, $\mathrm{pH}$, humidity, and duration of the heat treatment.

Yellowish pulp fruits presented higher total phenol content (112.80 mg EAG $100 \mathrm{~g}^{-1}$ ) (Table 3), which is closer to values found by Prates et al. (2015) in fresh canjiqueira pulp (152.57 mg EAG $\left.100 \mathrm{~g}^{-1}\right)$, native fruit of wide occurrence in Mato Grosso do Sul.

The $\mathrm{CI}_{50}$ values obtained were statistically different, 32.15 and $5.05 \mathrm{~g} \mathrm{~g} \mathrm{~g}^{-1}$ DPPH for extracts of orange and yellowish pulps, respectively (Table 3 ). It is important to highlight that the lower the value found, the higher the antioxidant capacity of fruit (LUZIA; JORGE, 2010), highlighting the high antioxidant potential of bocaiuva pulp obtained from yellowish pulp morphotype. According to Bianchi and Antunes (1999), antioxidants have the ability to reduce chain reactions and lesions caused by free radicals, delaying or inhibiting cell aging.

Jellies elaborated with yellowish pulp fruits presented higher content and retention of total phenols

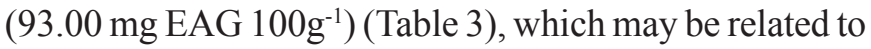
the higher amount of pulp added in this formulation due to the adjustment of the jelly consistency during processing. Similar values were found by Falcão et al. (2007) in grape jelly obtained without addition of pectin and with addition of xanthan gum and locust (95.1 mg EAG $100 \mathrm{~g}^{-1}$ ), with grape being known to be rich in antioxidants. According to Roesler et al. (2007), the demand for natural antioxidants has increased significantly, mainly for use in the food, pharmaceutical and cosmetic areas. The inclusion of antioxidants in the diet is of great importance for humans, since the consumption of foods rich in this category of compounds, such as fruits, contributes to reduce the risk of developing diseases related to the accumulation of free radicals (POMPELLA, 1997).

As for the evaluated centesimal composition parameters of bocaiuva pulps, there were no statistical differences between morphotypes, except for the fixed mineral residue content, in which the yellowish color had higher value $(1.89 \%)$ (Table 4$)$, indicating higher amount of minerals in its composition, and for fibers, in which the orange color showed higher content (7.40\%). Thus, mean values of moisture, total lipids, proteins and carbohydrates were $47.26 \%, 13.96 \%, 1.96 \%$ and $29.13 \%$, respectively, for orange pulp fruits, and $47.73 \%, 15.77 \%, 1.74 \%$ and $27.61 \%$, respectively, for yellowish pulp fruits (Table 4).

The moisture contents were lower than those found by Sanjinez-Argandoña and Chuba (2011), in bocaiuva fruits collected in Presidente Epitácio and Dourados (52.08\% and $51.13 \%$, respectively), while fixed mineral residues and lipids were higher than those found by 
Orsi et al. (2015), in bocaiuva pulp (1.37\% and 5.78\%, respectively). Comparing protein and carbohydrate contents with those found by Rocha et al. (2013), in the Cerrado of Piaui $(0.6 \%$ of proteins and $36.4 \%$ of carbohydrates), it was verified that in this work, values were higher for proteins and lower for carbohydrates. Silva et al. (2008) found values of $11.14 \%$ of fibers in bocaiuva pulp, higher than those found in this study.

Jellies of both morphotypes, in the same way as pulps, did not differ statistically with respect to composition, except for the fixed mineral residue, which was higher in both yellowish pulp and jelly, 1.89 and $0.47 \%$ respectively, and for fibers, with orange jelly having the highest content, $0.66 \%$ (Table 4). According to Menezes et al. (2016), dietary fiber in the diet favors intestine regulation, has the ability to reduce glycemic response and plasma cholesterol levels.

The mean values of moisture, lipids, proteins, carbohydrates and fibers were $27.19 \%, 0.73 \%, 0.58 \%$, $70.20 \%$ and $0.66 \%$, respectively, for orange pulp jellies, and $28.84 \%, 0.63 \%, 0.62 \%, 68.12 \%$ and $0.46 \%$, respectively, for those with yellowish pulp. The caloric value of orange pulp jelly was $289.74 \mathrm{kcal} 100 \mathrm{~g}^{-1}$ and that of yellowish, $252.19\left(\mathrm{kcal}^{100 \mathrm{~g}^{-1}}\right)$ (Table 4).

The moisture of jellies was reduced in relation to that of pulps (Table 4) due to the technological process of sugar addition and concentration, and in a similar way to that found by Lago-Vanzela et al. (2011), in cajá jelly $(29.5 \%)$. The values obtained for carbohydrates and caloric value were similar to those found in araçá jelly by Damiani et al. (2012), of $69.97 \%$ and $285.04 \mathrm{kcal}^{1} 100 \mathrm{~g}^{-1}$, respectively.

The lipid contents found in bocaiuva jellies (Table 4) were higher than those found in murici jelly $(0.12 \%)$ by Monteiro et al. (2015). It is important to highlight that bocaiuva fruits present large amounts of total lipids, especially oleic acid (omega 9) (ALVES et al., 2012), which is related to healthier triglyceride levels, helping reduce LDL (bad cholesterol) and increase HDL (good cholesterol) (NAGARAJU; LOKESH, 2007). The protein content obtained in jellies was higher than in Housui pear jelly (0.17\%), reported by Foppa et al. (2009) and in traditional umbu-cajá jelly $(0.25 \%)$ by Oliveira et al. (2014).

The scores assigned by judges for sensory acceptance differed statistically from all parameters evaluated, except for consistency. Jelly made with orange pulp presented higher averages, with scores above 5.83, where 5 represents "liked slightly" and 7, "liked very much", indicating that it was superior to that of yellowish pulp. When analyzing the purchase intention, tasters would possibly buy the orange pulp jelly, while they had doubts in the purchasing of yellowish pulp jelly (Table 5).

Jelly made with orange pulp had acceptability index higher than $80 \%$ for parameters global aspect (85.71\%), flavor $(87.29 \%)$, consistency $(83.29 \%)$ and purchase intention $(83.40 \%)$, while for orange pulp, acceptability indexes were $77.14 \% ; 77.29 \% ; 78.43 \%$ and $68.20 \%$, respectively (Figure 1). According to Dutcosky (2013), acceptability indexes greater than $70 \%$ are considered good for marketing.

The pulps of both morphotypes can provide products with distinct characteristics and greater possibility of adding value to regional products with high nutritional value.

The elaboration of bocaiuva jellies evidences the great potential of consumption and commercialization of this new product, allowing the generation of income to farmers of the Cerrado and Pantanal regions, State of Mato Grosso do Sul. It is applicable to bench scales, pilot plant and to subsidize operations used at commercial or industrial level in the agroindustry.

Table 1 - Physical characteristics of bocaiuva fruits of two morphotypes, orange and yellowish pulp.

\begin{tabular}{lcc}
\hline \multirow{2}{*}{ Characteristics } & \multicolumn{2}{c}{ Fruits } \\
\cline { 2 - 3 } & Orange pulp & Yellowish pulp \\
\hline Unit mass / whole fruit (g) & 27.40 & 16.41 \\
Bark (\%) & 16.57 & 16.57 \\
pulp (\%) & 53.36 & 39.79 \\
Equatorial diameter (mm) & $34.83 \mathrm{a}$ & $29.34 \mathrm{~b}$ \\
Longitudinal diameter (mm) & $35.15 \mathrm{a}$ & $29.85 \mathrm{~b}$ \\
Manual peeling $\left(\mathrm{kg} \mathrm{h}^{-1}\right)$ & $2.87 \mathrm{a}$ & $1.04 \mathrm{~b}$ \\
Manual pulping $\left(\mathrm{kg} \mathrm{h}^{-1}\right)$ & $1.36 \mathrm{a}$ & $0.70 \mathrm{~b}$ \\
\hline
\end{tabular}

Means followed by equal letters in the line do not differ from each other by the $\mathrm{F}$ test $(\mathrm{p}<0.05)$. 
Table 2- Color of shell and pulp of bocaiuva fruits of two morphotypes, orange and yellowish pulp.

\begin{tabular}{lccccc}
\hline \multirow{2}{*}{ Analyses } & \multicolumn{2}{c}{ Bark } & & \multicolumn{2}{c}{ Pulp } \\
\cline { 2 - 3 } \cline { 6 - 6 } & Orange pulp & Yellowish pulp & & Orange & Yellowish \\
\hline $\mathrm{L}^{*}$ & $42.18 \mathrm{a}$ & $40.86 \mathrm{a}$ & & $57.47 \mathrm{~b}$ & $60.93 \mathrm{a}$ \\
$\mathrm{a}^{*}$ & $10.95 \mathrm{a}$ & $6.60 \mathrm{~b}$ & & $19.25 \mathrm{a}$ & $13.17 \mathrm{~b}$ \\
$\mathrm{~b}^{*}$ & $40.22 \mathrm{a}$ & $35.86 \mathrm{~b}$ & & $71.81 \mathrm{a}$ & $63.59 \mathrm{~b}$ \\
\hline
\end{tabular}

Means followed by equal letters in the line do not differ from each other by the $\mathrm{F}$ test $(\mathrm{p}<0.05)$.

Table 3 - Chemical characterization of fresh pulps and jellies made with bocaiuva fruits of two morphotypes, orange and yellowish pulp.

\begin{tabular}{lccccc}
\hline \multirow{2}{*}{ Analyses } & \multicolumn{2}{c}{ Pulp } & & \multicolumn{2}{c}{ Jelly } \\
\cline { 2 - 3 } \cline { 5 - 6 } & Orange & Yellowish & & Orange & Yellowish \\
\hline Soluble solids ( ${ }^{\circ}$ Brix) & $9.27 \mathrm{a}$ & $9.10 \mathrm{a}$ & & $67.50 \mathrm{a}$ & $61.50 \mathrm{~b}$ \\
SS/TA (Ratio) & $24.39 \mathrm{a}$ & $21.16 \mathrm{a}$ & & - & - \\
pH & $5.79 \mathrm{a}$ & $6.00 \mathrm{a}$ & & $3.93 \mathrm{a}$ & $3.25 \mathrm{~b}$ \\
Ascorbic acid (mg 100 g-1) & $57.35 \mathrm{a}$ & $59.34 \mathrm{a}$ & & $10.69 \mathrm{a}$ & $12.34 \mathrm{a}$ \\
Total phenols (mg EAG 100g-1) & $99.95 \mathrm{~b}$ & $112.80 \mathrm{a}$ & & $47.72 \mathrm{~b}$ & $93.00 \mathrm{a}$ \\
Antioxidant capacity $\left(\mathrm{g} \mathrm{g}^{-1} \mathrm{DPPH}\right)$ & $32.15 \mathrm{~b}$ & $5.05 \mathrm{a}$ & & $71.73 \mathrm{~b}$ & $22.53 \mathrm{a}$ \\
\hline
\end{tabular}

Means followed by equal letters in the line do not differ from each other by the $\mathrm{F}$ test $(\mathrm{p}<0.05)$.

Table 4 - Centesimal composition of fresh pulps and jellies made with bocaiuva fruits of two morphotypes, orange and yellowish pulp.

\begin{tabular}{|c|c|c|c|c|}
\hline \multirow{2}{*}{ Analyses } & \multicolumn{2}{|c|}{ Pulp } & \multicolumn{2}{|c|}{ Jelly } \\
\hline & Orange & Yellowish & Orange & Yellowish \\
\hline Moisture & $47.26 \mathrm{a}$ & $47.73 \mathrm{a}$ & $27.19 \mathrm{a}$ & $28.84 a$ \\
\hline Fixed mineral residue & $1.47 \mathrm{~b}$ & $1.89 \mathrm{a}$ & $0.30 \mathrm{~b}$ & $0.47 \mathrm{a}$ \\
\hline Total lipids & $13.96 a$ & $15.77 \mathrm{a}$ & $0.73 a$ & $0.63 \mathrm{a}$ \\
\hline Proteins & $1.96 \mathrm{a}$ & $1.74 \mathrm{a}$ & $0.58 \mathrm{a}$ & $0.62 \mathrm{a}$ \\
\hline Carbohydrates & $29.13 a$ & $27.61 \mathrm{a}$ & $70.20 \mathrm{a}$ & $68.12 \mathrm{a}$ \\
\hline Fibers* & $7.40 \mathrm{a}$ & $5.37 \mathrm{~b}$ & $0.66 \mathrm{a}$ & $0.46 b$ \\
\hline $\mathrm{TCV}^{* *}\left(\mathrm{kcal} 100 \mathrm{~g}^{-1}\right)$ & $245.90 \mathrm{a}$ & $258.47 \mathrm{a}$ & $289.74 \mathrm{a}$ & $280.70 \mathrm{a}$ \\
\hline
\end{tabular}

*Fiber by difference. ${ }^{* *}$ Total Caloric Value.

Table 5 - Results (mean, $\mathrm{n}=70$ ) of scores attributed by judges for the sensory acceptance of the two-morphotype jellies, orange and yellowish flesh pulp formulations.

\begin{tabular}{lcc}
\hline \multirow{2}{*}{ Analyses } & \multicolumn{2}{c}{ Jelly } \\
\cline { 2 - 3 } & Orange pulp & Yellowish pulp \\
\hline Global aspect & $6.00 \mathrm{a}$ & $5.40 \mathrm{~b}$ \\
Flavor & $6.11 \mathrm{a}$ & $5.41 \mathrm{~b}$ \\
Consistency & $5.83 \mathrm{a}$ & $5.49 \mathrm{a}$ \\
Purchase intention & $4.17 \mathrm{a}$ & $3.41 \mathrm{~b}$ \\
\hline
\end{tabular}

Means followed by equal letters in the line do not differ from each other by the F test $(\mathrm{p}<0.05)$. Scores from 1 (strongly disliked) to 7 (liked very much) and for purchase intention from 1 (certainly would not buy) to 5 (certainly would buy). 


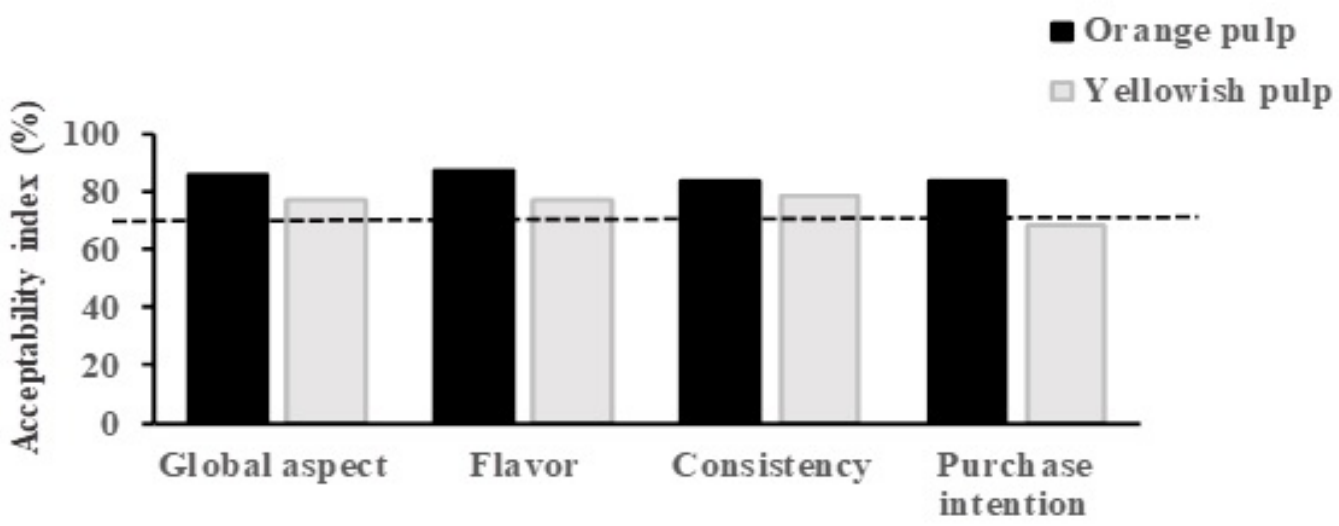

Figure 1 - Acceptability index of the two-morphotype jelly formulations, orange and yellowish pulp.

\section{Conclusion}

Orange pulp bocaiuva fruits present higher pulp yield and the peeling time is shorter. Yellowish pulp and the jelly elaborated with this pulp present higher levels of total phenols and antioxidant capacity. Orange pulp jelly was preferred by tasters and has higher fiber content.

\section{References}

AlVES, S. A.; OlIVEIRA, L. C. P.; PORTO, A. G.; SILVA, F. S.; SILVA, F. T. C.; NEVES, E. Extração e avaliação do rendimento de óleo da polpa de bocaiuva. Revista Citino, Joinville, v.2, n.3, p.32, 2012.

AOAC. Official methods of analysis of the Association of Official Analytical Chemists International. $16^{\text {th }} \mathrm{ed}$. Washington, 1997. p.37-45.

BERBARI, S.A.G.; PASCHOALINO, J.E. Acidificação do palmito pupunha In: PASCHOALINO, J.E. Industrialização do palmito pupunha. Campinas: Instituto de Tecnologia de Alimentos, 1997. cap.3, p.2330. (Manual Técnico, 15).

BIANCHI, M.L.; ANTUNES, L.M. Radicais livres e os principais antioxidantes da dieta. Revista Nutrição, Campinas, v.12, p.123-130, 1999.

BIANCHINI, M.G.A; COUTINHO, R.S.P. Fabricação de doces e geleias. 2.ed. Brasília, DF: LK Editora, 2007. $192 \mathrm{p}$.

BRANDÃO, E.M.; ANDRADE, C.T. Influência de fatores estruturais no processo de gelificação de pectinas de alto grau de metoxilação. Polímeros, São Carlos, v.9, n.3, p.3844, 1999. Disponível em: $\leq$ scielo.br/scielo.php?script=sci arttext\&pid=S0104-14281999000300008\&lng=en\&nrm= iso $>$. Acesso em: 05 Mar. 2018.
BRASIL. Resolução nº 12 de março de 1978. Aprova Normas Técnicas Especiais, do Estado de São Paulo, revistas pela CNNPA, relativas a alimentos e bebidas, para efeito em todo território brasileiro. Diário Oficial da União da República Federativa do Brasil, Brasília, DF, 24 jul. 1978, Seção 1, p.11.528. Disponível em: $\leq$ http:// www.anvisa.gov.br/anvisalegis/resol/12 78.pdf $>$. Acesso em: 25 mar. 2016.

INSTITUTO ADOLFO LUTZ. Normas Analíticas do Instituto Adolfo Lutz: métodos químicos e físicos para análise de alimentos. 4.ed. São Paulo, 2005. p.1020.

COUTO, M.A.L.CANNIATTI-BRAZACA, S.G. Quantificação de vitamina C e capacidade antioxidante de variedades cítricas. Ciência e Tecnologia de Alimentos, Campinas, v.30, p.15-19, 2010.

DAMIANI, C.; SILVA, F.A.; ASQUIERI, E.R.; LAGE, M.E.; VILAS BOAS, E.V.B. Antioxidant potential of Psidium guinnensis Sw. jam during storage. Pesquisa Agropecuária Tropical, Goiânia, v.42, n.1, p.90-98, $2012 b$.

DUTCOSKY, S.D. Análise sensorial de alimentos. 3.ed. Curitiba: Champagnat, 2011. 426 p.

DUTCOSKY, S.D. Análise sensorial de alimentos. 4.ed. Curitiba: Champagnat, 2013. $531 \mathrm{p}$.

FALCÃO, A. P.; CHAVES, E. S.; KUSKOSKI, E. M.; FETT1, R.; FALCÃO, L. D; BORDIGNON-LUIZ, M. $\mathrm{T}$. Índice de polifenóis, antocianinas totais e atividade antioxidante de um sistema modelo de geleia de uvas. Ciência e Tecnologia Alimentos, Campinas, v.27, n.3, p.637-642, 2007. 
FOPPA, T; TSUZUKI, M.M; SANTOS, C.E.D. Caracterização físico-química da geleia de pera elaborada através de duas cultivares diferentes: pera d'água (Pyrus communis L.) e housui (Pyrus pyrifolia Nakai). Revista Brasileira de Produtos Agroindustriais, Campina Grande, v.11, n.1, p.21-25, 2009.

GOMES, R.B; SANTOS, M.B; CARDOSO, R.L; TAVARES, J.T.Q; CUNHA, D.S. Elaboração e avaliação físico-químico e sensorial de geleia de maracujá com cenoura. Enciclopédia Biosfera, Goiânia, v.9, n.16, p.2765, 2013.

JACKIX, M.H. Doces, geleias e fruta em calda: teórico e prático. 2.ed. São Paulo: Editora da Unicamp, 1988. $98 \mathrm{p}$.

LAGO-VANZELA, E.S.; RAMIN, P.; GUEZ-UMSZA, M.A.; SAMTPS, G.V.; GOMES, E. DA SILVA, R. Caracterização química e sensorial de geleia da casca e polpa de cajá-manga (Spondias cytherea Sonn). Ciência e Tecnologia de Alimentos, Campinas, v.31, n.2, p.398405, 2011

LORENZI, H.; SOUZA, H.M.; MEDEIROS, J.T.; CERQUEIRA, L.S.C.; FERREIRA, E. Palmeiras no Brasil, nativas e exóticas. Nova Odessa: Plantarum, 1996.

LUZIA, D.M.M.; JORGE, N. Potencial antioxidante de extratos de sementes de limão (Citrus limon). Ciência e Tecnologia de Alimentos, Campinas, v.30, n.2, p.489493, 2010.

MATA, A.M.O.F; CARVALHO, R.M., ALENCAR, M.V.O.B., CAVALCANTE, A.A.C.M.; SILVA, B.B. Ácido ascórbico na prevenção e no tratamento do câncer. Revista da Associação Médica Brasileira, Teresina, v.62, n.7, p.680-686, 2016.

MENEZES E.W.; GRANDE, F.; GIUNTINI, E.B.; LOPES, T.V.C.; DAN, M.C.T.; PRADO, S.B.R.; FRANCO,B.D.G.M.; CHARRONDIÈRE U.R.; LAJOLO F.M. Impact of dietary fiber energy on the calculation of food total energy value in the Brazilian Food Composition Database. Food Chemistry, London, v.193, p.128-133, 2016.

MINOLTA CORP. Precise color communication: color control from feeling to instrumentation. Ramsey: Minolta Corporation Instrument Systems Division, 1994. $49 \mathrm{p}$.
MONTEIRO, D.C.B; SOUZA, W.C; PIRES, C.R.F; AZEVEDO, L.T; BORGES, J.S. Caracterização físicoquímica do fruto e da geleia de murici (Brysonima crassifólia). Enciclopédia Biosfera, Goiânia, v.11, n.21, p.3356, 2015.

MORAIS, S.M.; CAVALCANTI, E.S.B.; COSTA, S.O.; AGUIAR, L.A. Ação antioxidante de chás e condimentos de grande consumo no Brasil. Brazilian Journal of Pharmacognosy, João Pessoa, v.19, n.1, p.315-320, 2009.

NAGARAJU, A.; LOKESH, B.R. Interesterified coconut oil blends with groundnut oil or olive oil exhibit greater hypocholesterolemic effects compared with their respective physical blends in rats. Nutrition Research, New York, v.27, n.9, p.580-586, 2007.

NELLIS, S.C.; CORREIA, A. de F. K.; SPOTO, M. H. F. Extração e quantificação de carotenoides em minitomate desidratado (Sweet Grape) através da aplicação de diferentes solventes. Brazilian Journal Food Technology, Campinas, v.20, e2016156, 2017.

OLIVEIRA, E.N.A.; SANTOS, D.C.; ROCHA, A.P.T.; GOMES, J.P. Desenvolvimento, caracterização e estabilidade de geleia tradicional de umbu-cajá. Revista Brasileira de Fruticultura, Jaboticabal, v.36, n.3, p.640651, 2014.

ORSI, D.C.; NISHI, A.C.F.; CARVALHO, V.S.; BRANDÃO, C.C.; CARVALHO, A.A.; ASQUIERI, E.R. Caracterização química da polpa de macaúba (Acrocomia aculeata). Journal of Fruits and Vegetables, Rio de Janeiro, v.1, n.1, p.45-48, 2015.

POMPELLA, A. Biochemistry and histochemistry of oxidant stress and lipid peroxidation. International Journal of Vitamin and Nutrition Research, Bern, v.67, n.5, p.289-297, 1997.

PRATES, M.F.O.; CAMPOS, R.P.; SILVA, M.M.B.; MACEDO, M.L.R.; HIANE, P.A.; FILHO, M.M.R. Potencial nutritivo e antioxidante de frutos de canjiqueira afetados pelo estádio de maturação e pelo processamento térmico. Ciência Rural, Santa Maria, v.45, n.3, p.399404, 2015.

RAMOS, M.I.L.; RAMOS FILHO, M.M.; HIANE, P.A.; BRAGA NETO, J.A.; SIQUEIRA, E.M.A. Qualidade nutricional da polpa de bocaiuva Acrocomia aculeata (Jacq.) Lodd. Ciência e Tecnologia de Alimentos, Campinas, v.28 p.90-94, 2008. 
ROCHA, M.S.; FIGUEIREDO, R.W.; ARAÚJO, M.A.M.; MOREIRA-ARAÚJO, S.R. Caracterização físico-química e atividade antioxidante (in vitro) de frutos do cerrado piauiense. Revista Brasileira de Fruticultura, Jaboticabal, v.35, n.4, p.933-941, 2013.

ROESLER, R.; MALTA, L.G.; CARRASCO, L.C.; HOLANDA, R.B.; SOUZA, C.A.S.; PASTORE, G.M. Atividade antioxidante de frutas do cerrado. Ciência e Tecnologia de Alimentos, Campinas, v.27, n.1, p.53-60, 2007.

SALIS, S.M.; MATTOS, P.P. Floração e frutificação de bocaiuva (Acrocomia aculeata) e do carandá (Copernicia alba). Corumbá: Embrapa Pantanal, 2009. 6 p. (Comunicado Técnico, 78).

SANJINEZ-ARGANDOÑA, E. J; CHUBA, C. A. M. Caracterização biométrica, física e química de frutos da palmeira bocaiuva Acrocomia aculeata (Jacq) Lodd. Revista Brasileira de Fruticultura, Jaboticabal, v.33 n.3, p.1023-1028, 2011.

SANTOS JÚNIOR, J.F.; SPACKI, V.; SANTANA, F.P.; COSTA, D.C.; LORENZI, G.M.A.C. Bocaiuva, macaúva, macaúba, bocajá, técnicas e dicas de aproveitamento. Campo Grande: ECOA, 2012. 44p.

SILVA, M.R.; LACERDA, D.B.C.L.; SANTOS, G.G.; MARTINS, D.M.O. Caracterização química de frutos nativos do cerrado. Ciência Rural, Santa Maria, v.38, n.6, p.1790-1793, 2008.
SUCUPIRA, N.R.; XEREZ, A.C.P.; SOUZA, P.H.M. Perdas Vitamínicas Durante o Tratamento Térmico de Alimentos. UNOPAR Científica. Ciências Biológicas e da Saúde, Londrina, v.14, n.2, p.121-8, 2012.

SWAIN, T.; HILLS, W.E. The phenolics constituents of prumus domestica: the quantitative analysis of phenolic constituents. Journal of the Science of Food and Agriculture, London, v.10, n.1, p.63-68, 1959.

VIANNA, S.A. Caracterização da variabilidade fenotípica de Acrocomia aculeata (Jacq) Lodd. ex Mart. (Arecaceae): Etnobotânica, Morfologia, Produtividade e Composição nutricional. 2011. 61 f. Dissertação de Mestrado (Biologia Vegetal) - Universidade Federal de Mato Grosso do Sul, Campo Grande, 2011.

VIANNA, S.A.; POTT, A.; SILVA, R.H.; MOURA, E.B.; MARANHÃO, H.L.; SILVA, N.D.C.; BORSATO, A.V.Phenotypical Characterization of Acrocomia aculeata Fruits in Natural Populations in the Pantanal Region, Mato Grosso do Sul, Brazil. Acta Horticulturae, The Hague, v.1003, p.169-172. 2013.

ZIMMERMANN, A. M; KIRSTEN, V.R. Alimentos com função antioxidante em doenças crônicas: uma abordagem clínica. Ciências da Saúde, Santa Maria, v.9, n.1, p.5168, 2008. 